\title{
Invited Editorial
}

\section{The CFTC and commodity-based exchange-traded funds}

\author{
Philip McBride Johnson \\ Skadden, Arps, Slate, Meagher \& Flom LLP, 1440 New York Avenue, N.W., \\ Washington, D.C. 20005, USA; Tel: +1 202371 7340; Fax: +1 202661 9081; E-mail: \\ pjohnson@skadden.com
}

Philip McBride Johnson has devoted nearly all his 43 years in the practice of law to the US laws, regulations and agencies governing the markets in futures contracts, options, swaps and other 'derivative instruments'. His career includes: past chairman of the Commodity Futures Trading Commission (CFTC); leader of exchange-traded derivatives law practice, Skadden, Arps, Slate, Meagher \& Flom LLP and Affiliates; author of the dominant legal treatise on US derivatives law, 'Derivatives Regulation' (formerly 'Commodities Regulation') (3 vols, Aspen Law \& Business), of a business book: 'Derivatives: A Manager's Guide to the World's Most Powerful Financial Instruments' (McGraw-Hill); and of over 160 other published works; founder and first chairman of the derivatives law committees for both the American Bar Association and the International Bar Association; member of the regulatory advisory committee of the New York Stock Exchange (1989-2004); member of five CFTC federal advisory committees; laid the legal foundation for the first-ever: stock options exchange, cash-settled futures, stock index, interest rate and event futures, centralised federal regulator; referenced in Marquis' 'Who's Who in America', 'Who's Who in American Law' and 'Chambers US'.

When the Commodity Futures Trading Commission (CFTC) was created in 1975, there was little reason to think that its interests and those of the Securities and Exchange Commission (SEC) would ever clash. After all, there were no futures contracts on securities in the US, and the SEC would have little reason to want to regulate transactions in soybeans, silver or sugar. A few of us knew at the time, however, that the Chicago Board of Trade was designing a futures contract based on a mortgage-backed security known breathlessly as the Government National

Derivatives Use, Trading \& Regulation, certificate or 'Ginnie Mae', and that the
Vol. 11 No. 4, 2006, c pp. 303-307 (C) Palgrave Macmillan Ltd
$1747-4426 / 06 \$ 30.00$
CBOT's next step would be futures on US Treasury securities. ${ }^{1}$
When these new products were launched under CFTC jurisdiction and over SEC objections, a campaign lasting many years was conducted by the SEC to wrest from the CFTC any authority over futures which involved securities by striking a phrase in the Commodity Exchange Act giving the CFTC 'exclusive jurisdiction' over all futures contracts, irrespective of the underlying asset. ${ }^{2}$ The effort failed entirely until 1982, when certain futures markets expressed for the first time a strong interest in listing futures contracts on equity stock indexes such as the Dow Jones Industrial Averages and the S\&P500 index of corporate stocks. Congress, while not receptive to the SEC's earlier proposals for wholesale transfer of jurisdiction from the 
CFTC to the SEC for all security-related futures, had expressed misgivings on several occasions about the role of the CFTC if and when futures contracts were proposed that related to corporate stocks and bonds. Thus, the futures markets were proposing in 1982 to cross that Rubicon, and a bitter conflict between the two agencies, likely to be won by the larger SEC, loomed.

To assuage that concern, the SEC and the CFTC entered into an 'Accord' '3 which confirmed the CFTC's exclusive jurisdiction over certain futures contracts on large stock indexes and on most government securities but banned both agencies from authorising futures trading in single corporate securities or in smaller stock indices. Although not part of the inter-agency Accord, Congress engrafted onto the deal a right of the SEC to veto the CFTC's approval of any stock index futures contract if the SEC believed that it did not meet agreed standards.

While the Accord gave the SEC a role to play when futures contracts involve securities, it did not vest in the SEC any day-to-day regulatory authority. By 2000, however, several futures markets were urging Congress to lift the ban on single-stock and narrow-based stock index futures, expressing for the first time their willingness to involve the SEC in those products' regulation. With the enactment of the Commodity Futures Modernization Act of 2000 (the CFMA), the SEC became co-regulator with the CFTC over these instruments. $^{4}$

Such is the history of the SEC's quest for a role when futures contracts offer an opportunity to participate in the economics of a security. Today, however, we are observing the successful launch of instruments with exactly the opposite linkage, namely, securities that are linked directly with commodity prices or even with commodity futures prices. Called 'exchange traded funds' or ETFs, these instruments are commonly tied in value either entirely or predominantly to the price of gold, crude oil or some other commodity, and may be settled or redeemed using the published prices of a CFTC-regulated futures exchange. Just as one might have viewed security futures as a way to trade securities indirectly, the ETFs are just as surely a way to 'play' the commodity markets.

It remains to be seen whether the Congress, as it did in the CFMA, will follow the same policy and assign a co-regulatory role to the CFTC over these ETFs because of their linkage with commodity prices. To date, there is no indication of congressional desire to do so, and the CFTC itself has made no formal request to co-regulate these ETFs. The question arises, however, whether the CFTC enjoys any current authority over the ETFs linked to a commodity or valued off futures prices.

- Are commodity-linked ETFs really 'futures contracts? A starting point is whether these ETFs are in fact 'futures contracts' because they are designed to mimic the same economic behaviour. For example, could an ETF that derives its value from the changing price of gold (or gold futures) be classified as itself a gold futures contract? $?^{5}$ If so, the CFTC continues to enjoy exclusive regulatory 
jurisdiction over futures on commodities, and it would not be within the authority of the SEC to regulate or even to authorise them. At least one federal appeals court has held that, if an instrument is a futures contract that has not been statutorily designated for co-regulation by the SEC, it is subject to the CFTC's sole and exclusive jurisdiction even if it is also a security. ${ }^{6}$

- Are ETFs real 'securities'? Another threshold question is whether ETFs should be treated as 'securities' at all, as the US Supreme Court has ruled for many years that an instrument is a 'security' only if it derives its value solely, primarily or substantially from the efforts of persons other than the investor. ${ }^{7}$ A commodity-linked instrument, which derives its value from the market forces of supply and demand rather than from the managerial skills or acumen of third parties, might falter under this standard.

Clearly, any effort to promote either of those conclusions would be vigorously opposed by the issuers of ETFs and, most probabaly, by the SEC as well.

- What other powers could CFTC assert over ETFs? If these ETFs are not treated as futures contracts within the CFTC's exclusive jurisdiction, and if they are treated as securities subject to SEC regulation, it would appear that the CFTC has few, if any, remedies at its disposal except through aggressive interpretations of its powers.

- Antifraud. The CFTC has very limited antifraud enforcement power with respect to transactions involving physical commodities. ${ }^{8}$ If, however, the ETFs are structured as options and therefore might be viewed as 'commodity options' for which the CFTC has an antifraud provision ${ }^{9}$ very similar to that of the SEC, the CFTC might consider invoking it for ETF fraud. Such an effort, however, would confront a provision of the CFTC's enabling legislation appearing to foreclose the CFTC from regulating security options. $^{10}$

- Price manipulation. Moreover, the CFTC has well-established jurisdiction to prosecute price manipulations, not only in the futures markets but in the underlying physical markets for commodities. In the event that the CFTC might suspect that ETF trading is causing a manipulation of prices for the related futures market or underlying commodity, it could consider an investigation into the matter and, if warranted, seek to prosecute the offender(s) for violation of the Commodity Exchange Act. ${ }^{11}$

In addition, the CFTC might take the view that an ETF linked to a commodity is itself a 'commodity' under the broad definition set forth the Commodity Exchange Act, which encompasses 'rights' or 'interests', because ETFs convey to investors an undivided interest in the performance of a commodity and the right to share in its results. On this analysis, the CFTC might take the position that any attempted or achieved manipulation of the 
price of the ETF itself is a forbidden commodity manipulation.

Or, the CFTC might assert that commodity-linked ETFs fall within its realm as 'excluded commodities' under the Act. That phrase explicitly covers any price index, occurrence or contingency that neither party to the transaction can control. ${ }^{12}$ Here, neither the issuer nor the investor controls the behaviour of the underlying commodity. Again, were the ETF to be viewed as an 'excluded commodity', the CFTC might attempt to prosecute any perceived manipulation of its price.

The reality is that commodity-linked ETFs rest squarely within the domain of the SEC at this time and can be expected to remain there. In recent years, the CFTC has relaxed its insistence on exclusive jurisdiction with respect to various agreements - including what are clearly futures contracts - when the transactions are confined to certain types of parties, ${ }^{13}$ has surrendered any claim to regulate swap agreements between the same types of parties ${ }^{14}$ and, most relevant, has abandoned entirely any authority to oversee trading in securities that are linked to commodity prices even when the security's value is completely set by commodity prices and even if it is sold to the general public. ${ }^{15}$

In this process, the CFTC has also relinquished its power to confine all commodity futures and commodity options trading to CFTC-regulated markets. As a result, investors now have rich choices, for instance, to trade gold or another commodity on any of the following bases
- physical gold without federal regulation

- swap agreements on gold prices without federal regulation ${ }^{16}$

- over-the-counter gold futures, options or other agreements without federal regulation $^{16}$

- listed gold futures contracts under CFTC regulation

- gold ETFs under SEC regulation

- futures on Gold ETFs under joint CFTC/SEC regulation

- options on Gold ETFs under SEC regulation

- options on futures on Gold ETFs under joint CFTC/SEC regulation.

Whether this plethora of venues and regulatory outcomes for essentially the same transaction is welcomed or criticised, it poses a risk - not present under the CFTC's former centralised-market policy of fragmentation that could make each of these markets less liquid, impair their use for hedging protection, increase credit exposures and make less reliable and representative the prices emerging from each of them. Those risks seem remote today, as the CFTC-regulated exchanges boast historically high volumes and open interest. Over time, however, this may be another matter.

(C) Philip McBride Johnson

\section{References and Notes}

1 The author served as principal outside counsel to the Chicago Board of Trade during a period from roughly 1967 to 1981.

2 Commodity Exchange Act 2(a)(1)(C), 7 USC. 2. The Act covered a list of farm products as well as 'all other goods and articles ... and all services, 
rights and interests in which contracts for future delivery are presently and in the future dealt in.' See Act 1a(4), 7 USC. 1a. The author contributed this language to Congressional staff. In 2000, the concept of a 'commodity' was broadened even further with the addition of 'any occurrence, extent of an occurrence, or contingency ... that is ... beyond the control of the parties ... and ... associated with a financial, commercial, or economic consequence.' See Act 1a(13), 7 USC. 1a. Thus, in addition to physical assets, the Act covers futures contracts involving intangibles, events and abstractions.

3 The author, as CFTC chairman, executed what became known as the Shad/Johnson Accord on 7th December, 1981.

4 Although many provisions of the statutes governing the CFTC and the SEC were amended to achieve co-regulation, see eg Commodity Exchange Act 2(a)(1)(D), 7 USC. 2.

5 This would not be the first time the CFTC reviewed whether an instrument bearing a different name was truly a futures contract. As early as 1987, the CFTC openly discussed whether to treat as futures contracts a number of instruments including 'swaps.' 52 Fed. Reg. 47002 (11th December, 1987), reprinted at [1987-90 Transfer Binder] Comm. Fut. L. Rep. $(\mathrm{CCH})$ 23,995. In 1989, the CFTC characterised most swap transactions as 'possessing elements of futures or options contracts' but declined to regulate them as such based on other considerations. 54 Fed. Reg. 30694 (21st July, 1989), reprinted at [1987-90 Transfer Binder] Comm. Fut. L. Rep. (CCH) 24,494.

6 Board of Trade of the City of Chicago $v$ Securities and Exchange Commission, 677 F.2d 1137 (7th Cir. 1982).

7 Securities and Exchange Commission $v$ W. J. Howey Co., 328 US 293 (1946). See also SEC v Glenn W. Turner Enterprises, Inc., 474 F.2d 476 (9th Cir. 1973) and SEC v Koscot Interplanetary, Inc., 497 F.2d 473 (5th Cir. 1974).

8 Commodity Exchange Act 4b, 7 USC. 6b. For instance, fraud related to physical commodities must be committed by a member of a CFTC-designated contract market acting on behalf of the defrauded person and must involve a transaction on or under the rules of a CFTC-licensed market. Otherwise, the prohibition applies only to fraud by an intermediary related to futures contracts being handled on behalf of the defrauded person.

9 CFTC Regulation 32.9, 17 C.F.R. 32.7. This provision is patterned closely after SEC Rule 10b-5, 17 C.F.R. 240.10b-5.

10 Commodity Exchange Act 2(a)(1)(C)(i), 7 USC. .

11 Commodity Exchange Act 9(a)(2), 7 USC. 13.

12 Commodity Exchange Act 1a(13), 7 USC. 1a.

13 See Commodity Exchange Act 2(d), 7 USC. 2.

14 See Commodity Exchange Act 2(g), 7 USC. 2.

15 Commodity Exchange Act 2(f), 7 USC. 2.

16 Subject to meeting statutory eligibility requirements. 